\title{
Modelling Innovative Activity In The New Zealand Biotechnology Sector
}

\author{
Dan Marsh $^{a}$ and Les Oxley ${ }^{b}$ \\ ${ }^{a}$ Department of Economics, University of Waikato \\ ${ }^{b}$ Department of Economics, University of Canterbury
}

This paper describes results from an investigation into the determinants of biotechnology innovation in New Zealand using a comprehensive new dataset. The theoretical framework is based on a synthesis of hypotheses drawn from four strands of the innovation literature and the empirical work utilises Poisson regression methods. The data provides strong support for the idea that smaller enterprises (whether measured by number of biotech graduates or by biotech expenditure) tend to have a higher innovation rate and is in line with other studies reported in the literature. However, the result requires further exploration

Keywords: Biotechnology, innovation, Poisson regression.

\section{Introduction}

The new economy has been variously identified with productivity statistics, globalisation, the knowledge economy and specific technologies affecting particular sectors. Freeman (1995), suggests that a new group of technologies should meet five conditions if they are to have major effects on the economy. They should i) create a new range of products accompanied by improvements in the technical characteristics of many products and processes; ii) bring about a reduction in the costs of many products and services; iii) be socially and politically acceptable; iv) be environmentally acceptable; and v) have pervasive effects throughout the economic system. Modern biotechnology clearly meets the first condition. The jury is still out on the Freeman's second condition: "so far biotechnology has led to profitable innovations in only a relatively small number of applications in a few sectors in a few countries" (Freeman, 1995, p. 15). New Zealand along with many other countries is in the middle of a heated debate about whether biotechnology is socially, politically or environmentally acceptable. The outcome with respect to these first four conditions will determine the extent to which it has "pervasive effects throughout the economic system".

Innovation provides a common theme in much of the discussion about the new economy. A review of the economic literature in this area reveals much common ground. Most authors agree that stock of ideas, innovative effort, technological opportunity, demand, market structure, appropriability, spillovers and institutional factors are all important.
The argument has moved on from discussion of demand-pull (Schmookler, 1966) vs. technologypush (Rosenberg, 1974), or the effects of firm size (Cohen, 1995) to a more integrated approach. Dosi's 1988 article provides an excellent summary of the 'state of the art' from an evolutionary perspective. What is the relative importance of different explanatory variables? How do these vary in different industries or organisational types? What are the most effective policy levers? These questions have increasing relevance for policy makers as more and more governments seek to improve the innovative performance of their economies.

This paper aims to make a contribution to the literature. The extent of modern biotechnology use in New Zealand is outlined in section 2, based on a comprehensive new dataset covering almost all biotech enterprises. Section 3 sets out the theoretical framework and a series of innovation hypotheses relating to firm level factors. In the empirical section results are presented focussing on the effect of firm type, size and alliance strength on innovative output and innovation rate. The final section draws some conclusions both from the empirical data and from the practical experience of using national survey data to develop innovation indicators.

\section{$2 \quad$ Biotechnology in New Zealand}

Despite the small size of its economy and of its science base New Zealand has had a significant role in the biotechnology revolution. Most modern biotechnology activities in New Zealand are concentrated in universities and Crown Research 
Institutes (CRI) and a small number of private sector companies e.g. Genesis, Virionyx, ViaLactia. The government has been estimated to spend around NZ\$190m pa on biotechnology-related research ranging from genomics to processing of natural products. Only a small proportion of this is spent on research involving genetic modification (NZ\$18 million in 2000). Biotechnology-related research comprises around $17 \%$ of total spending on 'the Science Envelope' (NZ\$586 million in 1999/2000). Genesis has invested over NZ\$80 million in research since its inception in 1994 while CRI's and companies such as Auckland UniServices have also been successful in generating research revenue from outside the government sector.

Modern biotechnology R\&D is undertaken by approximately 57 enterprises (15 primary product and manufacturing firms, 24 research organisations and 6 universities) employing around 1700 people. Modern biotech activity was split fairly evenly between the private sector (30 enterprises) and the public sector (27 enterprises). They reported expenditure on biotech of NZ\$202 million and income from biotech of NZ\$236 million. A further 36 enterprises used modern biotech processes (but were not engaged in R\&D) and employed around 1000 people in 'biotech based activities', which provided income of NZ\$112 million. Theoretical Framework

\section{Theoretical Framework}

The theoretical framework for this work is based on hhypotheses drawn from four strands of the innovation literature: industrial organisation (Scherer, 1980), theories of innovation at the level of the cluster, network or technological system e.g. (Carlsson \& Stankiewicz, 1991; Porter, 1990), endogenous growth theory (Romer, 1990) and the literature on national systems of innovation (Freeman, 1987; Lundvall, 1992; Nelson, 1993).

In this framework, innovation is held to be a deliberate activity that is usually undertaken to solve economic problems or capitalize on economic opportunities (Schmookler, 1966, p. 207). Innovation results from research and development and various other kinds of learning activity that are usually undertaken in the expectation of gaining economic benefits. The level of innovation can be directly related to the amount of effort put into R\&D, the existing stock of ideas (Romer, 1990), firm level factors and to supply side forces that determine the probability of success e.g. technological opportunity and the cost of producing a successful invention (Rosenberg, 1974, p. 103). Innovative output is also affected by market structure (e.g. numbers of buyers and sellers, barriers to entry) and the extent to which firms can appropriate the economic benefits of their innovations. R\&D spending has spillover effects both between enterprises and internationally. There has been a particular focus in recent years on the role of various kinds of linkage between the different players in clusters or systems of innovation. The quality and quantity of these links are an important determinant of innovative output. This paper concentrates on testing the effect of firm level factors; firm size and type, number of ideas workers and R\&D and alliance characteristics on innovative output and innovation rate.

The hypotheses tested are necessarily limited by the variables included in the 1998/99 Biotechnology Survey. The remainder of this section will outline the hypotheses tested in the empirical section of this paper alongside a brief discussion of their background in the innovation literature.

Hypothesis 1: Innovation output and innovation rate vary with firm or organisational type

Hypothesis 2: Enterprises that specialise in biotechnology have a higher innovative output compared to those that are not specialised.

Hypothesis 3: Enterprises that conduct R\&D have a higher innovative output and innovation rate than those that do not.

Hypothesis 4: Enterprises that use modern biotech processes have a higher innovative output and innovation rate than those that use traditional processes only.

Hypothesis 5: Innovation output and innovation rate increase with the quantity and quality of interaction between organisations making up the innovation system

Hypothesis 6: International linkages have a stronger positive effect than domestic linkages.

Hypothesis 7: Innovation output and innovation rate increase with enterprise size

Hypothesis 8: Innovation rate increases with the number of ideas workers (and the stock of ideas)

\section{Data: The 1998/99 Biotechnology Survey}

In 1999 the Ministry of Research Science and Technology (MORST) commissioned Statistics New Zealand to investigate the use of biotechnology in New Zealand. The main purpose 
was to "produce statistics concerning the present position of this industry in New Zealand. A descriptive analysis of the results from the survey can be found in Statistics New Zealand (2001) and Marsh (2001). Questionnaires were sent to 426 enterprises that had been identified as possible users of modern biotechnology processes. The survey achieved a $98 \%$ response rate with 180 enterprises being identified as users of at least one biotechnology process. $52 \%$ of enterprises used modern biotechnology; $32 \%$ of these were also engaged in R\&D. The survey also included enterprises that use traditional biotech processes. $48 \%$ of survey respondents used traditional biotech processes $13 \%$ of these were also engaged in R\&D. $35 \%$ of respondents used traditional processes e.g. fermentation, extraction, diagnostic tests etc. and were not engaged in R\&D. Estimates on the size of the traditional biotech 'sector' cannot be regarded as being complete since a significant numbers of other users of such processes were not included in the survey, or reported that they did not use modern biotechnology. The empirical section seeks to relate indicators of innovative output (new products and processes and patents) to explanatory variables such as innovative effort, alliance strength and organisational type. All regressions were run using the full data set of 180 enterprises that use at least one biotechnology process.

In our analysis of data from the survey, modern biotechnology is defined as: (1) recombinant DNA technology, (2) use of antibodies (3) protein engineering (4) novel bioprocessing techniques. The term 'modern' is used to distinguish processes that have been developed in the last 30 years or so, from traditional biotech areas such as fermentation and extraction.

\section{Model Formulation}

Alternative indicators of innovative output were used based on the number of new products and/or processes introduced and the number of patents applied for. Combining these three gives a much improved measure since different organisations exhibit innovative output in different ways. Patents are a better indicator for enterprises that concentrate on the creation (and protection) of intellectual property, while the number of new products and/or processes introduced is a better indicator for more production-oriented enterprises (many of which have applied for few if any patents).

The effect of, firm size and innovative effort were investigated through creation of a series of dummy variables for total expenditure, biotech expenditure and various indicators for 'number of ideas workers'. In each case the sample was divided into quartiles. Three dummy variables were used to define membership of quartiles two to four with the first quartile being the constant. Food manufacturers were selected as the constant for industry group; being significantly different characteristics to groups such as research organisations and universities.

The basic model used to test the hypothesis that innovative output (Y) depends on a vector of firm level factors $(\mathrm{X})$ as detailed in Table 1:

$$
Y=\exp \left(\beta^{\prime} X\right)+u
$$

In general we expect to obtain positive coefficients indicating that innovative output increases with biotech expenditure, research intensity, strength of strategic alliance etc. Coefficients for industrial group indicate innovative output relative to food manufacturers (the constant).

\section{Table 1: List of Variables}

\begin{tabular}{|l|l|}
\hline Abbrev & Name \\
\hline Constant & \\
\hline innout & Innovative Output \\
\hline $\begin{array}{l}\text { d_bex1 to } \\
\text { d_bex3 }\end{array}$ & Dummies for Biotech Expenditure \\
\hline $\begin{array}{l}\text { d_tex1 to } \\
\text { d_tex3 }\end{array}$ & Dummies for Total Expenditure \\
\hline $\begin{array}{l}\text { d_grad1 to } \\
\text { d_grad3 }\end{array}$ & Dummies for No. of Biotech Graduates \\
\hline $\begin{array}{l}\text { d_bfte1 to } \\
\text { d_bfte3 }\end{array}$ & Dummies for No. of Biotech \\
\hline $\begin{array}{l}\text { d_tfte1 to } \\
\text { d_tfte3 }\end{array}$ & Dumployees \\
\hline $\begin{array}{l}\text { strategi } \\
\text { d_allnz } \\
\text { d_allov }\end{array}$ & Strategic Alliance \\
\hline $\begin{array}{l}\text { d_prim } \\
\text { d_nonfd } \\
\text { d_resear } \\
\text { d_locala } \\
\text { d_univ } \\
\text { d_health } \\
\text { d_other }\end{array}$ & \\
\hline narrow & Dummies for Industrial Group \\
\hline dum_rd & Dummy for R\&D \\
\hline pct_tota & Biotech Percentage \\
\hline rdtot_no & No. of Biotech Processes \\
\hline
\end{tabular}




\section{Empirical Results}

\subsection{Poisson Regression Results}

The model tested relates innovative output (innout) to enterprise size (using dummies for biotech expenditure $d$ bex), industry group, existence of biotech alliances (strategi), whether modern biotech processes used (narrow) and presence/strength of R\&D activity (dum_rd, rdtot_no and pct_tota).

The innovative output indicator is a count variable with characteristics that make it well suited to analysis using Poisson regression. Poisson regression is often used to model the number of occurrences of an event as a function of some independent variables.

Results from the Poisson regression suggest that all four hypotheses relating to firm type should be accepted. There are significant differences in innovative output between industry groups; the output of most groups being significantly higher than that of food manufacturers. The primary industry group had the highest innovative output followed by research organisations, non-food manufacturers, health, other and universities. The innovative output of New Zealand universities is not captured very well by our indicator based on new products/processes and patents; thus providing a possible explanation for their relatively low output. This will change if New Zealand follows US trends in the commercialisation of university-based research.

\section{Table 2: Poisson Regression Results}

\begin{tabular}{|llll|}
\hline Variable & Coeff & S.E & 'p' \\
\hline Constant & -2.198 & .317 & 0.000 \\
d_bex1 & .249 & .241 & 0.301 \\
d_bex2 & .928 & .225 & 0.000 \\
d_bex3 & 1.393 & .220 & 0.000 \\
d_prim & 2.281 & .296 & 0.000 \\
d_nonfd & 1.474 & .261 & 0.000 \\
d_resear & 1.669 & .254 & 0.000 \\
d_locala & .414 & .410 & 0.312 \\
d_univ & 1.086 & .299 & 0.000 \\
d_health & 1.424 & .276 & 0.000 \\
d_other & 1.550 & .311 & 0.000 \\
strategi & -.466 & .120 & 0.000 \\
narrow & .510 & .152 & 0.001 \\
dum_rd & .677 & .152 & 0.000 \\
rdtot_no & .042 & .005 & 0.000 \\
pct_tota & .006 & .001 & 0.000 \\
\hline Pseudo R ${ }^{2}$ & 0.4966 & & \\
Obs. & 180 & & \\
\hline
\end{tabular}

Alternative indicators of the presence and strength of $R \& D$ all had a positive and highly significant effect on innovative output; enterprises engaged in R\&D had additional IO of 0.68 , while those using modern biotech processes had additional IO of 0.51 . Enterprises using more biotech processes for R\&D had a higher IO; so for example use of 12 processes suggests additional IO of 0.5 . Specialisation (pct_tota) was also found to have a positive effect such that a dedicated biotech firm (pct_tota $=100)$ would have additional IO of 0.6. Taking all of these effects together we confirm hypotheses 2,3 and 4. Specialisation, R\&D and use of modern biotech processes all tend to increase innovative output.; so for example, a dedicated biotech firm, engaged in modern biotech $\mathrm{R} \& \mathrm{D}$ using 12 processes would have additional IO of 2.3 compared to a nonspecialised traditional biotech firm not engaged in R\&D.

Initial analysis (see Table 2) suggested that presence of a biotech alliance has a negative effect on innovative output. Some light was shed on this somewhat surprising result by separating out the effect of international and local (NZ based) alliances (see Table 3). This reveals a strong negative effect for New Zealand based alliances but suggests a positive effect for international alliances, thus supporting hypothesis 6. Table 3: Poisson Regression Results
(Separate NZ and Overseas Alliance)

\begin{tabular}{|llll|}
\hline Variable & Coeff & SE & 'p' \\
\hline Constant & -2.209 & .316 & 0.000 \\
d_bex1 & .210 & .242 & 0.385 \\
d_bex2 & .862 & .226 & 0.000 \\
d_bex3 & 1.358 & .220 & 0.000 \\
d_prim & 2.178 & .301 & 0.000 \\
d_nonfd & 1.429 & .261 & 0.000 \\
d_resear & 1.628 & .255 & 0.000 \\
d_locala & .456 & .409 & 0.265 \\
d_univ & 1.011 & .302 & 0.001 \\
d_health & 1.427 & .277 & 0.000 \\
d_other & 1.489 & .313 & 0.000 \\
d_allnz & -.666 & .143 & 0.000 \\
d_allov & .261 & .119 & 0.029 \\
narrow & .514 & .152 & 0.001 \\
dum_rd & .781 & .155 & 0.000 \\
rdtot_no & .041 & .005 & 0.000 \\
pct_tota & .006 & .001 & 0.000 \\
\hline Pseudo R & 0.5001 & & \\
Obs. & 180 & & \\
\hline
\end{tabular}


The negative effect reported above does not necessarily imply that hypothesis 5 should be rejected since the variable strategi simply records presence or absence of a biotech alliance and is unlikely to adequately reflect the quantity and quality of interaction through alliances. Attempts were made to determine whether an indicator of biotech alliance strength could explain variation in innovative output. Analysis was hampered by absence of a satisfactory indicator. The survey dataset includes the different types of organisations with which respondents formed alliances e.g. Crown Research Institutes, businesses, universities etc both in New Zealand and overseas but unfortunately respondents were not asked how many different organisations they had partnerships with. The alliance strength indicator (ALL) was calculated from: number of alliance purposes + number of NZ organization types + number of overseas organization types. It must be recognised that these variables are not necessarily correlated either with the total number of alliances formed, or with the strength and importance of those alliances. Poisson regression produced a coefficient value of 0.02 with a $\mathrm{p}$ value of 0.14 .

Poisson regression confirms the expected result that firms that spend more money on biotechnology have a larger innovative output. More specifically: enterprises in the top two quartiles for biotech expenditure have a significantly higher innovative output compared to those in the lowest quartile. This may be viewed as unsurprising; we would expect after all, that the innovative output of large enterprises would be greater than that of smaller ones. What is of much more interest is whether any systematic pattern of variation in innovation rate can be identified, where innovation rate is estimated from innovative output divided by some measure of firm size or innovative effort.

The coefficients for d_bex 1 - d_bex3 (dummies for biotech expenditure) are positive and increasing but the rate of increase is much lower than the difference in biotech expenditure underlying these dummy variables. This is highlighted by the fall in incidence rate ratios for d_bex 1 - d_bex 3 as biotech expenditure increases (not reported here). This result clearly suggests that higher levels of biotech expenditure produce diminishing returns in terms of innovative output. In other words, smaller enterprises tend to have a higher innovation rate. We support Cohen and Klepper's findings (1992; 1996b) and reject hypothesis 7 .

Significance levels are lower than for biotech expenditure but indicate a similar result. The innovative output of enterprises in the top two quartiles (for number of biotech employees or biotech graduates) is significantly higher than the constant group. Similarly the coefficients for d_bfte1 - d_bfte3 (dummies for biotech employees) are positive and increasing but the rate of increase is much lower than the difference in number of biotech employees underlying these dummy variables. Increasing the number of biotech employees produces diminishing returns in terms of innovative output so that smaller enterprises (whether measured by number of ideas workers or biotech expenditure) tend to have a higher innovation rate. Overall hypothesis 8 is not supported although this may be because our indicators do not adequately measure 'number of ideas workers' and because our data do not provide any usable measure of the stock of ideas.

Results for variables describing number of staff generally have lower significance levels and show some inconsistency in the coefficients. This is probably a data quality issue since there were methodological problems in deciding who was a biotech staff member and no question was asked about how many of these worked on biotech R\&D. A number of organisations with large numbers of biotech staff had a low innovative output and put little effort into R\&D while several small organisations were engaged almost exclusively in R\&D.

\section{Conclusions}

This paper has described an attempt to use data from the 1998/99 Biotechnology Survey to identify and quantify the factors affecting innovation in biotechnology. The expected positive relationship between innovative effort and innovative output has been confirmed and some significant differences between the innovative outputs and innovation rates of different organisational types have been identified. The data provides strong support for the idea that smaller enterprises (whether measured by number of biotech graduates or by biotech expenditure) tend to have a higher innovation rate. This finding although in line with other studies reported in the literature e.g (Arvanitis \& Hollenstein, 1996; Cohen \& Klepper, 1996a; Hansen, 1992) require further exploration. For example, what explains the higher innovation rate of smaller enterprises? Are small enterprises able to obtain innovation inputs from larger enterprises? What is the optimal mix of large and small enterprises? 


\section{Acknowledgements:}

We would like to thank Bonggeun Kim for excellent advice and guidance. We also acknowledge support from the Marsden Fund grant, UOC 108 .

\section{References}

Arvanitis, S., \& Hollenstein, H. (1996). Industrial Innovation in Switzerland: A Model-based Analysis with Survey Data. In A. Kleinknecht (Ed.), Determinants of Innovation (pp. 13-62): MacMillan.

Carlsson, B., \& Stankiewicz, R. (1991). On the Nature, Function, and Composition of Technological Systems. Journal of Evolutionary Economics, 1(2), 93-118.

Cohen, W. M. (1995). Empirical Studies of Innovative Activity. In P. Stoneman (Ed.), Handbook of the Economics of Innovation and Technological Change.: Blackwell.

Cohen, W. M., \& Klepper, S. (1992). The Tradeoff Between Firm Size and Diversity in the Pursuit of Technological Progress. Small Business Economics, 4(1), 1-14.

Cohen, W. M., \& Klepper, S. (1996a). Firm Size and the Nature of Innovation within Industries: The Case of Process and Product R\&D. Review of Economics and Statistics, 78(2) May, 232-243.

Cohen, W. M., \& Klepper, S. (1996b). A Reprise of Size and R\&D. Economic Journal, 106 (437) July, 925-951.

Dosi, G. (1988). Sources, Procedures, and Microeconomic Effects of Innovation. Journal of Economic Literature, 26 September, 1120-1171.

Freeman, C. (1987). Technology and Economic Performance: Lessons from Japan.: Pinter.

Freeman, C. (1995). Technological Revolutions: Historical Analogies. In M. Fransman \& G. Junne \& A. Roobeek (Eds.), The Biotechnology Revolution? Oxford: Blackwell.

Hansen, J. (1992). Innovation, Firm Size, and Firm Age. Small Business Economics, 4(1), 37-44.

Lundvall, B. (Ed.). (1992). National Systems of Innovation: Towards a Theory of Innovation and Interactive Learning. London: Pinter Publishers.

Marsh, D. (2001). Modern Biotechnology in New Zealand: Further Analysis of Data from the
Biotechnology Survey 1998/99. Hamilton: Department of Economics. http://ideas.uqam.ca/ideas/data/waieconwp.h tml.

Nelson, R. R. (Ed.). (1993). National Innovation Systems: A Comparative Analysis. New York: Oxford University Press.

Porter, M. (1990). The Competitive Advantage of Nations. London: MacMillan.

Romer, P. (1990). Endogenous Technological Change. Journal of Political Economy, 98(5) Part 2, S71-S102.

Rosenberg, N. (1974). Science, Invention and Economic Growth. Economic Journal, 84 March, 90-108.

Scherer, F. M. (1980). Industrial Market Structure and Economic Performance.: Houghton Mifflin.

Schmookler, J. (1966). Invention and Economic Growth. Cambridge, Mass: Harvard University Press.

Statistics New Zealand. (2001). Modern Biotechnology Activity in New Zealand. Wellington. http://www.stats.govt.nz.

New Technology-based Firms in the 1990s (Vol. VI). Amsterdam: Pergamon. 